\title{
JNK inhibition sensitises hepatocellular carcinoma cells but not normal hepatocytes to the TNF-related apoptosis-inducing ligand
}

\author{
S R Mucha, ${ }^{1}$ A Rizzani, ${ }^{1}$ A L Gerbes, ${ }^{1}$ P Camaj, ${ }^{2}$ W E Thasler, ${ }^{2}$ C J Bruns, ${ }^{2}$ S T Eichhorst, ${ }^{1}$ \\ E Gallmeier, ${ }^{1}$ F T Kolligs, ${ }^{1}$ B Göke, ${ }^{1}$ E N De Toni'
}

${ }^{1}$ University of Munich, University Hospital Grosshadern, Department of Medicine 2, Munich, Germany; ${ }^{2}$ University of Munich, University Hospital Grosshadern, Department of Surgery, Munich, Germany

Correspondence to:

Dr E N De Toni, University of Munich, University Hospital Grosshadern, Department of Medicine II, Research Lab B 5 E01 308, Marchioninistrasse 15 D-81377 Munich, Germany; enrico.detoni@

med uni-muenchen de

Revised 2 December 2008 Accepted 11 December 2008 Published Online First 23 December 2008

\section{ABSTRACT}

Background: cJun terminal kinase (JNK) is constitutively activated in most hepatocellular carcinomas (HCCs), yet its exact role in carcinogenesis remains controversial. While tumour necrosis factor (TNF)-related apoptosisinducing ligand (TRAIL) is known as a major mediator of acquired immune tumour surveillance, and is currently being tested in clinical trials as a novel cancer therapy, the resistance of many tumours to TRAIL and concerns about its toxicity in vivo represent obstacles to its clinical application. In this study we investigated whether JNK activity in HCC could contribute to the resistance to apoptosis in these tumours.

Methods: The effect of JNK/Jun inhibition on receptormediated apoptosis was analysed by pharmacological inhibition or RNA interference in cancer cells and nontumour cells isolated from human liver or transgenic mice lacking a phosphorylation site for Jun.

Results: JNK inhibition caused cell cycle arrest, enhanced caspase recruitment, and greatly sensitised HCC cells but not normal hepatocytes to TRAIL. TRAILinduced activation of JNK could be effectively interrupted by administration of the JNK inhibitor SP600125.

Conclusions: Expression and TRAIL-dependent feedback activation of JNK likely represent a mechanism by which cancer cells escape TRAlL-mediated tumour surveillance. JNK inhibition might represent a novel strategy for specifically sensitising HCC cells to TRAIL thus opening promising therapeutic perspectives for safe and effective use of TRAlL in cancer treatment.

Hepatocellular carcinoma (HCC) is one of the most common cancers worldwide, and its incidence is rising. To date, surgery is the only curative treatment available for those who qualify. The majority of patients, however, are not suitable candidates for surgery, and curative medical treatment is currently not available. Therefore, new therapeutic approaches are needed.

Loss of sensitivity to apoptosis is a hallmark of cancer. This is thought to occur through several mechanisms including loss of the death receptors TRAIL-R or CD95, or impairment of intracellular signalling pathways. ${ }^{2}$ Previous studies demonstrated enhanced primary tumour and metastases formation in mice after TRAIL-receptor blockage or in TRAIL-receptor knock-out mice; ${ }^{3}$ clinical studies have furthermore shown a correlation between loss of death receptors and dedifferentiation, tumour size, poor prognosis, and tumour recurrence. ${ }^{4}$ We have also recently shown that over-expression of the TRAIL-binding soluble decoy receptor osteoprotegerin (OPG) correlates with tumour stage and metastasis formation in patients affected by colon carcinoma. ${ }^{5}$ Activation of apoptosis signalling pathways in cancer cells otherwise resistant to apoptosis is therefore an important therapeutic strategy.

Due to its ability to induce apoptosis in cancer cells while leaving normal cells unharmed, TRAIL has become a promising candidate for tumour therapy. ${ }^{6}{ }^{7}$ While in vitro toxicity of TRAIL to non-tumour tissues varies greatly, depending on the experimental design and the type of TRAIL used, ${ }^{89}$ recent clinical trials seem to confirm the safety of TRAIL administration in vivo. ${ }^{10-12}$ In spite of these reassuring results, concerns about the safety of systemic administration of TRAIL remain, especially with regards to possible toxic effects on diseased organs. ${ }^{13}{ }^{14}$

A second, relevant, limitation to a therapeutic use of TRAIL is the resistance of about $50 \%$ of cancer cells to the activation of the receptormediated apoptotic pathway. ${ }^{15}$

Consequently, a future clinical use of TRAIL will have to confront the challenge of sensitising cancer cells to this molecule as well as minimising its cytotoxic effect on normal tissues. This prompts a reconsideration of known carcinogenic signal pathways regarding their contribution to resistance to receptor-mediated apoptosis. ${ }^{16-18}$

Through the phosphorylation of c-Jun and its activating protein-1 (AP-1) transcription activity, cJun $\mathrm{N}$-terminal kinase (JNK) regulates a wide spectrum of cellular activities in physiological conditions and has been shown to act pro- and anti-apoptotically in different cell types and experimental systems ${ }^{1920}$ (for a review, see the excellent work by $\mathrm{Czaja}^{19}{ }^{19}$. The fact that JNK might play a role in the pathogenesis of tumours is supported by the fact that this kinase is constitutively expressed in several tumours and in most hepatocellular carcinomas. ${ }^{21-25}$ The mechanisms through which JNK signalling affects the pathogenesis of tumours remain elusive, however.

We hypothesised that over-expression of JNK/ Jun in HCC contributes to the pathogenesis of tumours by specifically interfering with receptorinduced apoptosis. Targeting JNK might therefore represent the key to the successful use of TRAIL as a cancer treatment.

\section{MATERIALS AND METHODS}

Cell culture and siRNA tranfection

Chang, HepG2 and Huh7 cells were grown in RPMI medium (PAA Laboratories, Pasching, 
A

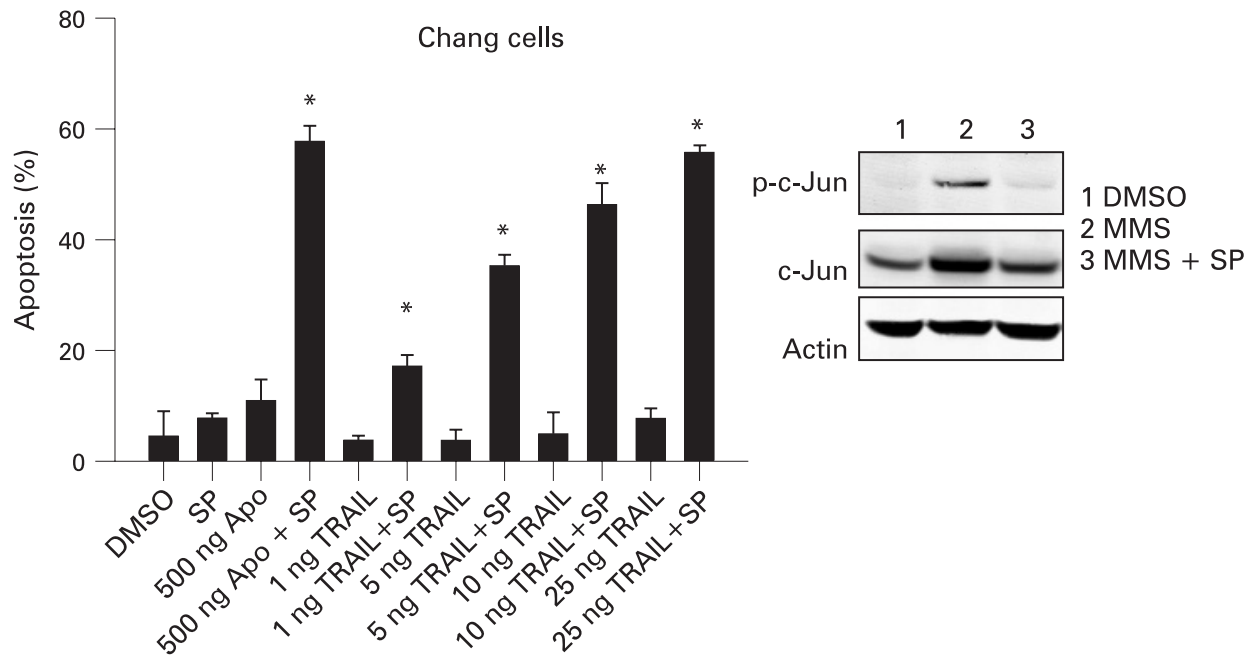

B

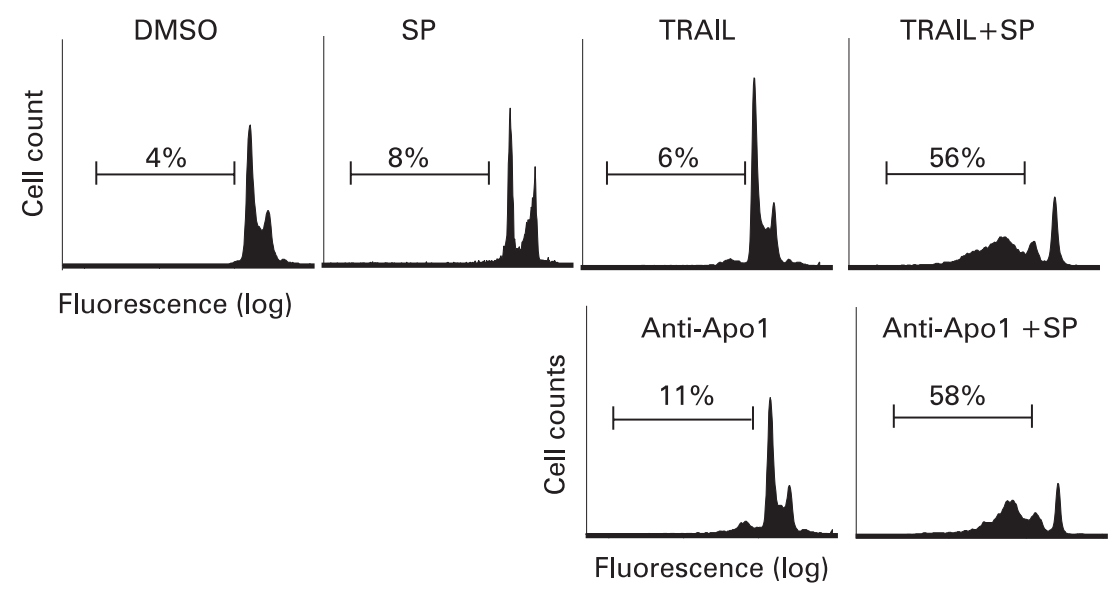

C

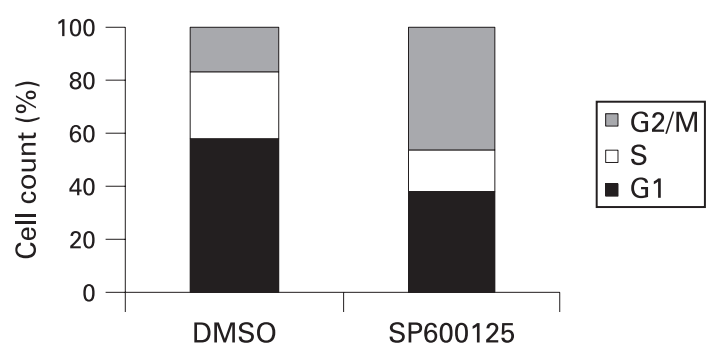

Figure 1 JNK inhibition enhances TRAIL-R- and CD95-mediated apoptosis. Here all experiments were performed in Chang hepatoma cells. (A) Left panel: apoptosis rates after treatment with SP600125 (SP, $20 \mu \mathrm{mol} / \mathrm{l})$, anti-Apo1 (Apo, $500 \mathrm{ng} / \mathrm{ml}$ ), TRAIL (at increasing concentrations of 1, 5, 10 and $25 \mathrm{ng} / \mathrm{ml}$ ), or combination of SP600125 with anti-Apo1 or TRAlL. Protein A was added at 0.01 times the concentration of anti-Apo1 to facilitate crosslinking of the antibody. DMSO $0.2 \%$ was used as control. $0.8 \times 10^{5}$ Chang cells per well were seeded in 12-well plates. After overnight incubation, cells were treated for $16 \mathrm{~h}$ as indicated. The bars indicate mean and SD of one representative experiment, performed in triplicate, and repeated at least three times. Sub G1-events were measured by FACS analysis after propidium iodide stain. Asterisks designate statistical significances as calculated by the $t$ test, comparing apoptosis rates of cells stimulated with anti-Apo1 or TRAIL in combination with SP600125 vs cells treated with anti-Apo1 or TRAIL in association with DMSO ( $<<0.001)$. Right panel: western blot analysis of phospho-c-Jun, c-Jun and actin (loading control) of same cells. $0.8 \times 10^{6}$ cells were seeded in $10 \mathrm{~cm}$ dishes. After overnight incubation, cells were treated with $20 \mu \mathrm{mol} / \mathrm{SPP} 60125$ or DMSO; where indicated $1 \mathrm{mmol}$ of MMS was added $30 \mathrm{~min}$ after SP600125 to induce c-Jun phosphorylation. $50 \mu \mathrm{g}$ of total protein per lane were separated by SDS-PAGE. (B) Representative flowcytometry pattern of Chang cells shown in A (for TRAlL the FACS pattern of cells treated with $25 \mathrm{ng} / \mathrm{ml}$ is shown). (C) Cell cycle analysis of Chang cells after treatment with DMSO or SP600125 for $24 \mathrm{~h}$. The G2 cell cycle phase was higher in SP600125-treated cells vs cells treated with DMSO, while the G1 and S phase remarkably lower (respective values: G2/M phase, 46.67 (SD 0.47) and 16.33 (SD 1.70), $p<0.005 ; \mathrm{S}$ phase, 16.0 (SD 0.82 ) and 25.33 (SD 1.25), $\mathrm{p}<0.01$; G1 phase, 37.33 (SD 0.94) and 57.67 (SD 0.47), $\mathrm{p}<0.005$ ). DMSO, dimethy sulfoxide; FACS, fluorescence-activated cell sorting; JNK, cJun N-terminal kinase; MMS, methyl methan sulfonate; SP, SP600125; TRAIL, tumour necrosis factor-related apoptosis-inducing ligand. 
Figure $2(\mathrm{~A}-\mathrm{F})$ Light and fluorescence microscopy features of Chang cells after Hoechst staining (left and right panels, respectively). Cells were analysed after $16 \mathrm{~h}$ incubation with TRAIL at the concentration of $5 \mathrm{ng} / \mathrm{ml}$ in the presence $(A, B)$ or absence $(C, D)$ of SP600125 (magnification, $\times 100$ ). Cells were washed, fixed in $6 \%$ formalin and stained with $250 \mu \mathrm{g} / \mathrm{ml}$ Hoechst 33342 for $1 \mathrm{~h}$ and then assessed by fluorescence microscopy. (E) At higher magnification $(\times 400)$ typical morphological features of cells undergoing apoptosis with membrane blebbing and shrinkage. (F) Chromatin condensation and nuclear fragmentation (arrows) in comparison to adjacent intact nuclei with Hoechst staining of cells in panel (E). TRAIL, tumour necrosis factor-related apoptosis-inducing ligand.
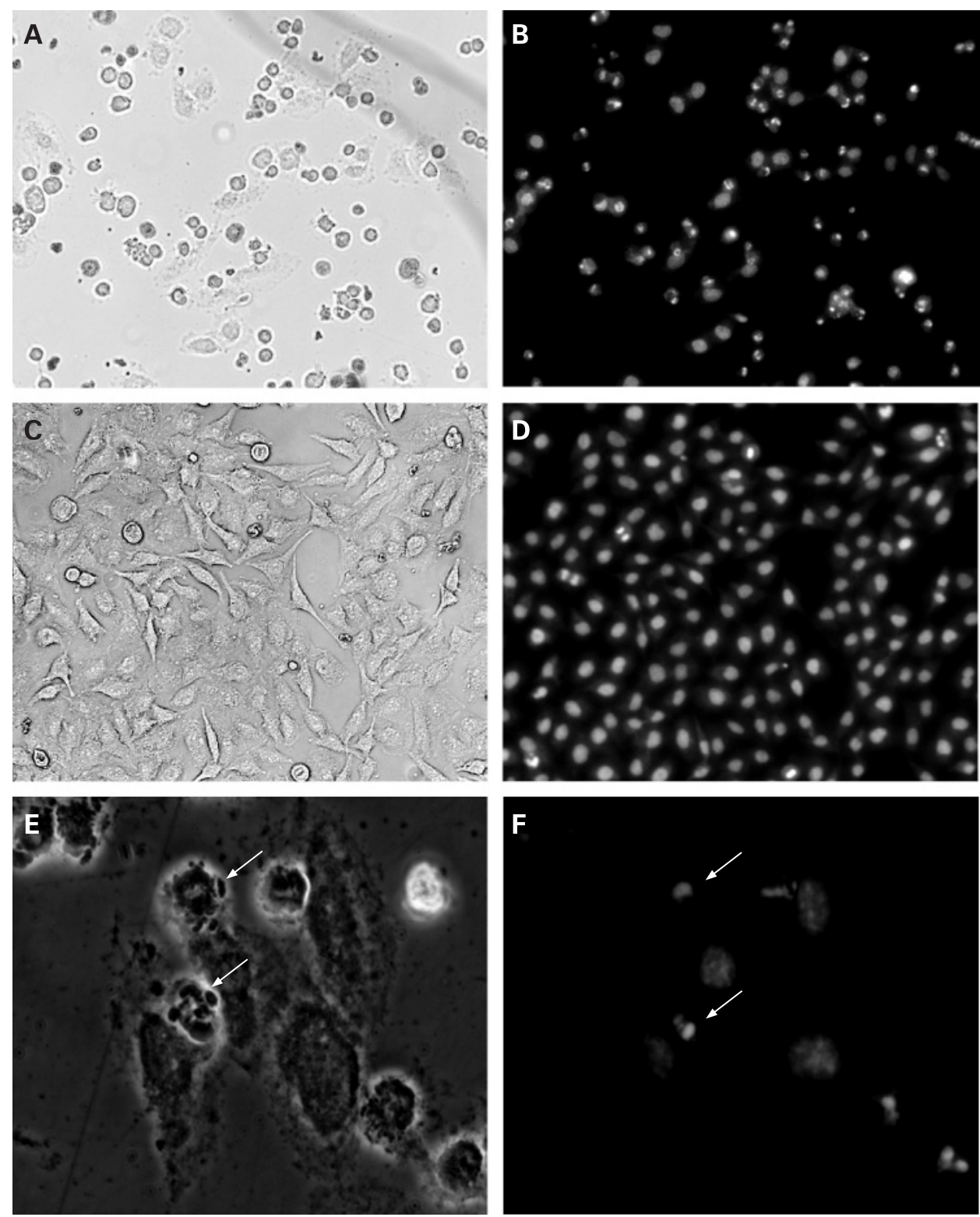

Austria), HepA1-6 cells were cultured in DMEM (Gibco BRL, Karlsruhe, Germany) supplemented with 10\% fetal calf serum (FCS) and 1\% penicillin-streptomycin (Gibco BRL). Tissue sample collection from human liver resections was performed according to the guidelines of the charitable state-controlled foundation Human Tissue and Cell Research (Regensburg, Germany). ${ }^{26}$ Human hepatocytes were isolated using a modified two-step EGTA/collagenase perfusion procedure as described previously. ${ }^{27}$ Mouse hepatocytes were isolated from A/A mice, lacking the phosphorylation site for $\mathrm{c}-\mathrm{Jun}^{28}$ or from syngenic wild-type mice. Cell viability, as determined by trypan blue exclusion, was typically $>90 \%$. Cells were plated on 6 -well plates $\left(5 \times 10^{5}\right.$ cells/well $)$ or 12 -well plates $\left(2 \times 10^{5}\right.$ cells/well, Biocoat; Becton Dickinson, Heidelberg, Germany) in William's E Medium (Gibco) containing 10\% FCS (Gibco), 1\% penicillin/ streptomycin and supplemented with cystein $(90 \mathrm{mg} / \mathrm{l})$ and methionin $(55 \mathrm{mg} / \mathrm{l})$. Cells were stimulated after overnight incubation. The JNK- and non-coding sequences used for siRNA transfection have been described previously. ${ }^{25}$ For c-Jun the following sequences were used. Sense: 5'-AAAAAAGGAAGCT GGAGAGAAT-3'; antisense: 5'-ATTCTCTCCAGCTTCCT
TT-3'. For transient transfection Oligofectamine (Invitrogen, Carlsbad, California, USA) was used according to the manufacturer's instructions.

\section{Reagents}

SP600125 was purchased from Tocris (Bristol, UK) and dissolved in dimethyl sulfoxide (DMSO). Anti-Apo1 antibody and LZCD95L were a kind gift of P Krammer (DKFZ, Heidelberg, Germany). TRAIL (Apo-2L, human recombinant) was purchased from Sigma (Taufkirchen, Germany; cat. number K4761-20UG). The pancaspase inhibitor Z-VAD-FMK was purchased from Promega (Mannheim, Germany), the caspase 8 inhibitor Z-IETD-FMK and the caspase 9 inhibitor Z-LEHD-FMK were purchased from BD Pharmingen (San Diego, California, USA); all were diluted in DMSO and added at the concentration of $20 \mu \mathrm{mol} / 1$.

Incubation of Chang cells with SP600125 also caused a G2/M cell cycle arrest. Fluorescence-activated cell sorting (FACS) analysis of DNA content showed a G2-phase cell cycle arrest after $24 \mathrm{~h}$ of treatment with SP600125, compared to cells treated with DMSO $(p<0.005)$ (fig $1 \mathrm{C})$. 
A

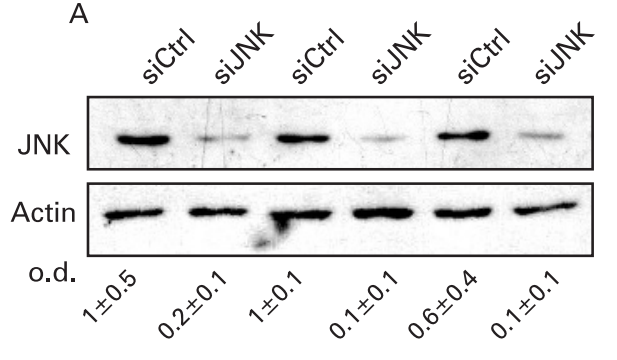

C

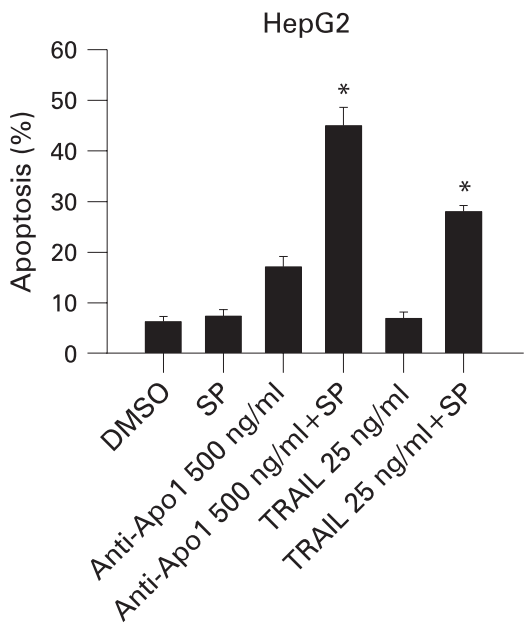

B
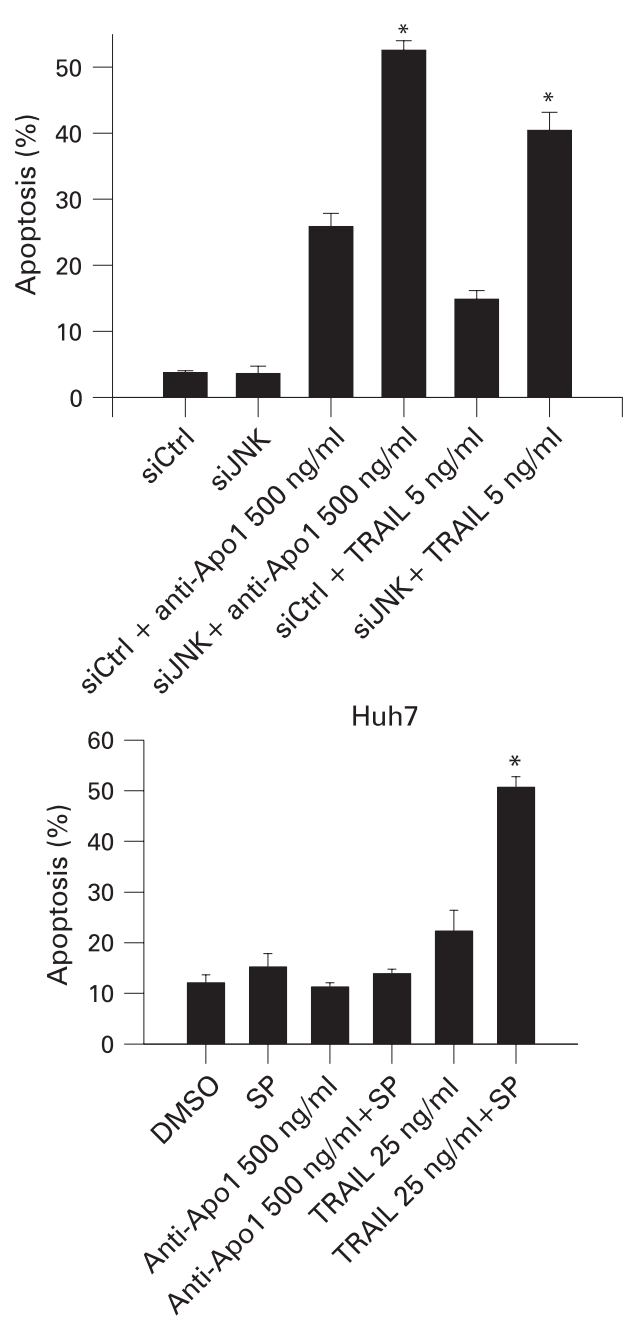

Figure 3 Sensitisation of hepatoma cells to apoptosis by SP600125 is a specific effect of JNK inhibition and is independent of cell line and p53 status. $(A, B)$ siRNA directed against JNK or control siRNA was transiently transfected into Chang cells. $10^{5}$ cells were seeded in 12 -well plates $24 \mathrm{~h}$ prior to transfection in RPMI medium without antibiotics. Transfection was carried out in OptiMEM (Gibco) without FCS, which was added after 4 h. After 48 h, anti-Apo1 (500 ng/ml) or TRAIL ( $5 \mathrm{ng} / \mathrm{ml}$ ) were added for $16 \mathrm{~h}$ where indicated. (A) Western blot analysis of JNK expression; Optical density (o.d.) expresses means and standard deviations of JNK versus actin of three different western blots. (B) FACS analysis by PI staining after JNK inhibition with siRNA or non-coding siRNA. Apoptosis rates (sub-G1 fractions) represent mean and standard deviation from triplicate samples from the same experiment; at least three other experiments gave similar results $\left({ }^{*} \mathrm{p}<0.001\right)$. (C) $0.8 \times 10^{5} \mathrm{HepG} 2$ and Huh7 cells per well were seeded in 12 -well plates. After overnight incubation, cells were treated for $16 \mathrm{~h}$ with anti-Apo1 $(500 \mathrm{ng} / \mathrm{ml})$ or TRAlL $(25 \mathrm{ng} / \mathrm{ml})$ alone or in combination with SP600125 as indicated. Graphs show mean apoptosis rates and standard deviation of one representative experiment, performed in triplicate, and repeated at least three times. DMSO, dimethyl sulfoxide; FACS, fluorescence-activated cell sorting; FCS, fetal calf serum; JNK, cJun N-terminal kinase; PI, propidium iodide; SP, SP600125; TRAIL, tumour necrosis factor-related apoptosis-inducing ligand.

\section{Apoptosis and membrane receptor assessment}

Apoptosis and cell cycle were analysed by assessing sub-G1 events or the respective cell cycle phases in the euploid cell fraction, using flow cytometry (FACScalibur, using Cell Quest software; Becton Dickinson) according to Nicoletti et al. ${ }^{29}$ Additionally, apoptosis was assessed morphologically by Hoechst 33342 staining (Sigma Chemical, Diesenhofen, Germany) and fluorescence microscopy (Carl Zeiss, Jena, Germany). The validity of FACS results in primary hepatocytes was confirmed by comparing the number of apoptotic cells observed after Hoechst staining (500 cells from four randomly chosen fields per treatment group), with sub-G1 events counted in FACS analysis. This comparison was done in triplicate using cells from two different donors. For assessment of membrane receptors, cells were detached from the plates by ethylenediaminetetraacetic acid (EDTA), washed and incubated for $1 \mathrm{~h}$ with the following monoclonal fluorescein isothiocyanate (FITC)-coupled antibodies: CD95 (556640) from BD Pharmingen, TRAIL-R1 (ALX-804-297F-T100), TRAIL-R2 (ALX-522-005FC050) and control mIgG1 (Alexis, San Diego, California, USA).

\section{Western blot analysis}

Briefly, proteins were separated by sodium dodecyl sulfate polyacrylamide gel electrophoresis (SDS-PAGE) and transferred to polyvinylidine difluoride (PVDF) membranes. After blocking for $1 \mathrm{~h}$ in $5 \%$ milk-Tris-buffered solution(TBS)-Tween solution, membranes were incubated with primary antibodies at $4^{\circ} \mathrm{C}$ overnight, followed by the appropriate secondary antibody for $1 \mathrm{~h}$ at room temperature. Bands were visualised using the 


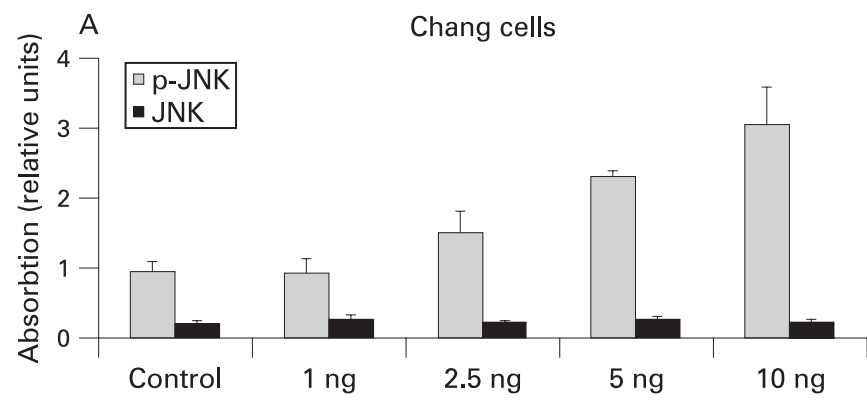

TRAIL concentration
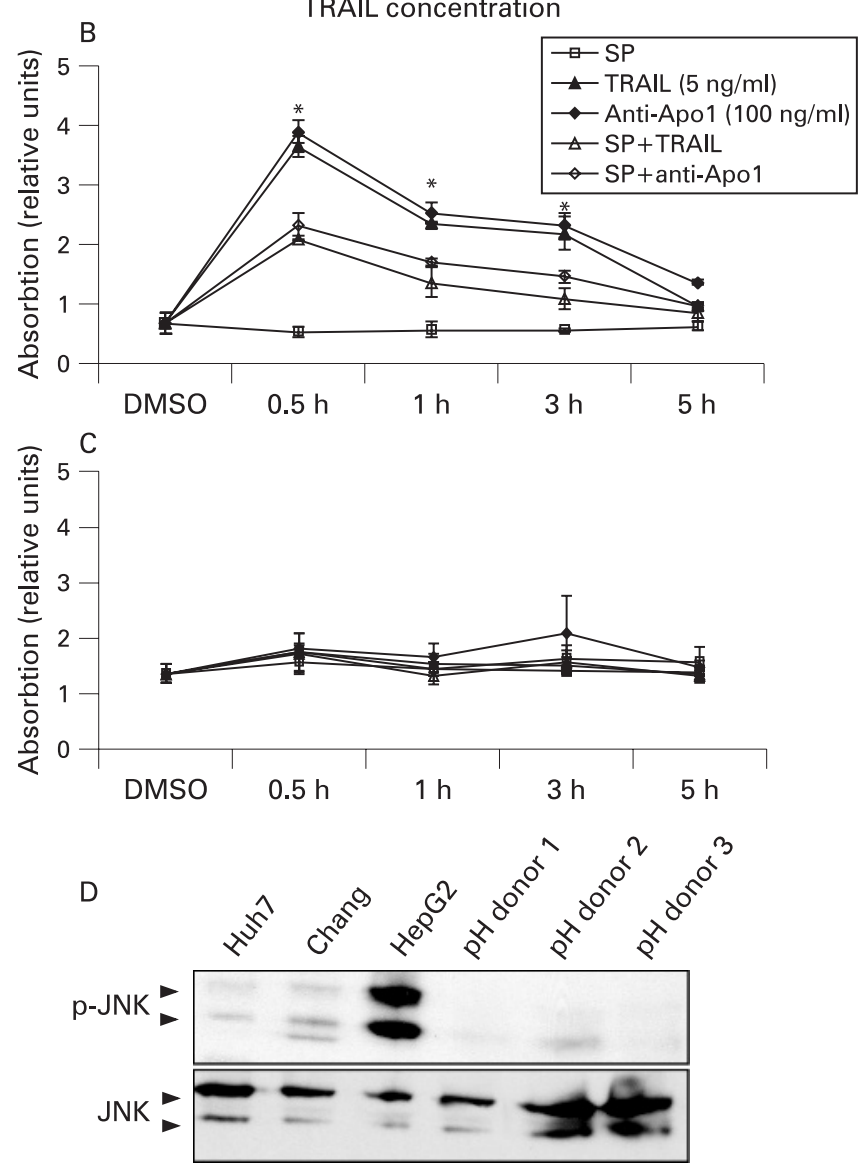

Figure 4 SP600125 inhibits TRAIL-R and CD95 mediated JNK activation. (A-C) Fast activated cell-based ELISA (FACE) analysis of $p$ JNK and JNK in Chang cells. Three thousand cells were seeded overnight in 96-well plates. Cells were treated for $1 \mathrm{~h}$ with increasing TRAIL concentrations (A). (B,C) Cells were treated with $5 \mathrm{ng} / \mathrm{ml}$ TRAlL, $100 \mathrm{ng} / \mathrm{ml}$ anti-Apo1, DMSO or $20 \mu \mathrm{mol} / \mathrm{l} \mathrm{SP600125}$ (SP) for $0.5,1,3$ or $5 \mathrm{~h}$ as indicated. Relative absorption was calculated using crystal violet stain to standardise for cell number of each sample according to the manufacturer's instructions ( ${ }^{*}$ values of TRAIL or anti-Apo1-treated cells significantly increased versus baseline value; $p<0.001$ ).

(D) Western blot of p-JNK and JNK in unstimulated Huh7, HepG2 and Chang hepatoma cells and primary hepatocytes $(\mathrm{pH})$ from three independent donors after overnight incubation. $35 \mu \mathrm{g}$ of protein were loaded in each lane. DMSO, dimethyl sulfoxide; JNK, cJun N-terminal kinase; TRAIL, tumour necrosis factor-related apoptosis-inducing ligand.

ECL system (Amersham, UK). The following antibodies were used: caspase 3 (Santa Cruz, H-277; Santa Cruz, California, USA), JNK (Santa Cruz, D-2), phospho-c-Jun (ser63) II (Cell Signaling, Beverly, New York, USA), c-Jun (BD Transduction), actin (ICN Biomedicals, Irvine, California, USA). Densitometric
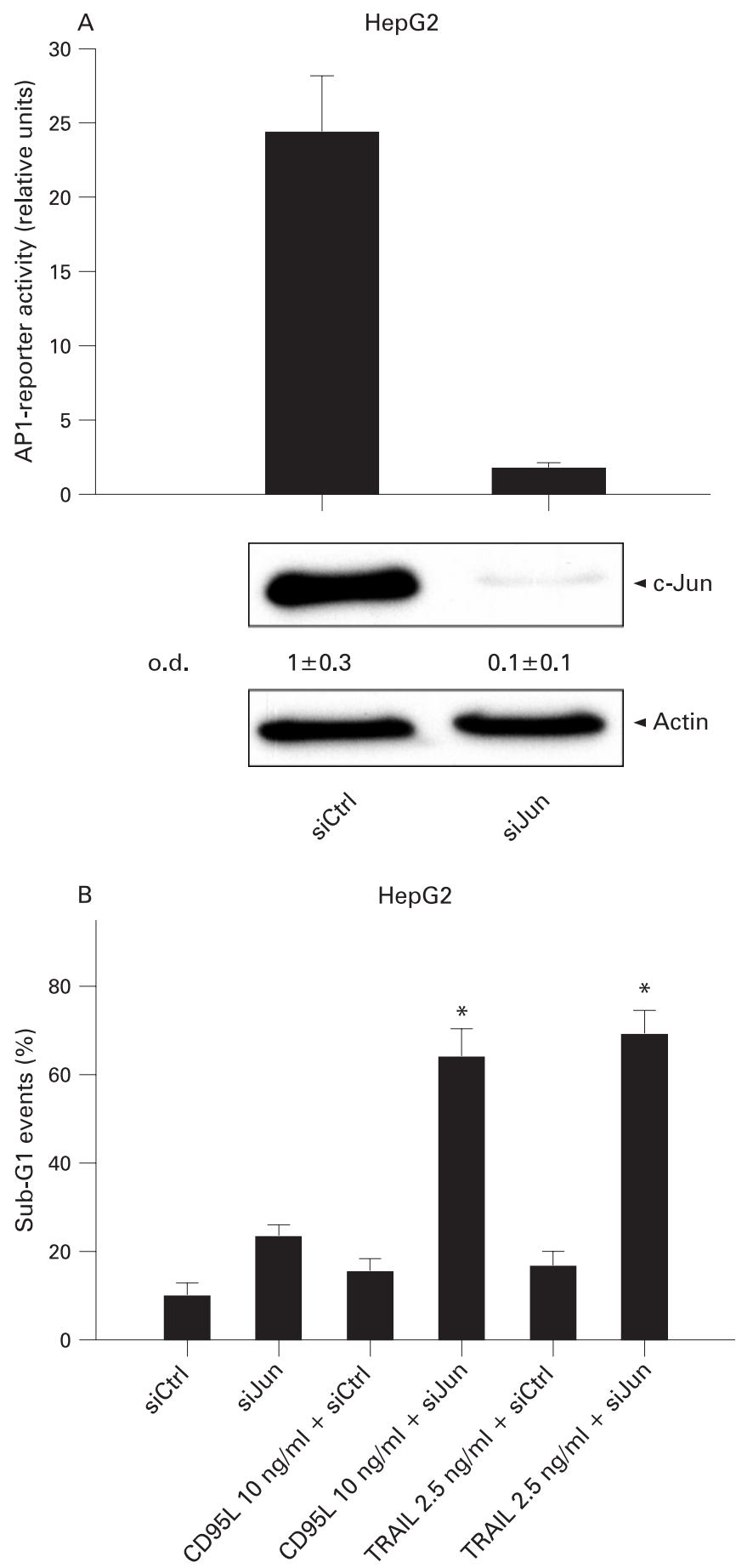

Figure 5 c-Jun inhibition enhances receptor mediated apoptosis. (A) Downregulation of c-Jun by c-Jun specific siRNA (siJun) or control non-coding siRNA (siCtrl) in HepG2 cells $24 \mathrm{~h}$ after transfection. Optical density (o.d.) shows average and standard deviation vs actin of three biological replicates. Upper panel shows inhibition of AP-1 transcriptional activity as consequence of c-Jun downregulation as measured by luciferase reporter assay. (B) Apoptosis rates after siRNA transfection and $16 \mathrm{~h}$ of incubation with either CD95 ligand $(10 \mathrm{ng} / \mathrm{ml})$ or TRAIL $(2.5 \mathrm{ng} / \mathrm{ml})$ in control-transfected cells vs c-Jun siRNA-transfected cells Apoptosis rates as measured by FACS after PI stain, are expressed as mean, error bars indicating standard deviation of one representative experiment, performed in triplicate and repeated at least three times $\left({ }^{*} p<0.001\right.$ vs control). AP-1, activating protein-1; FACS, fluorescenceactivated cell sorting; PI, propidium iodide; TRAIL, tumour necrosis factor-related apoptosis-inhibiting ligand. 
Figure 6 MAPK inhibition causes increased recruitment of caspase 8 and caspase 3 . $(A, B)$ Chang cells were treated with $5 \mathrm{ng} / \mathrm{ml}$ TRAlL in the presence or absence of SP600125. $50 \mu \mathrm{g}$ of protein were separated on $12 \% \mathrm{Bis} /$ Tris minigels. Fragments of cleaved caspase $3(\mathrm{~A})$ and caspase 8 (B) are indicated. (C) Chang cells were incubated and treated as in fig 1; TRAIL was added at a concentration of $5 \mathrm{ng} / \mathrm{ml}$; anti-Apo1 at a concentration of $100 \mathrm{ng} / \mathrm{ml}$. Additionally, the pancaspase inhibitor Z-VAD-FMK (PAN), the caspase 8 inhibitor Z-IETD-FMK (aC8) and the caspase 9 inhibitor Z-LEHD-FMK (aC9) were added, each at a concentration of $20 \mu \mathrm{mol} / \mathrm{l}$ ( ${ }^{*}$ each value significantly lower vs cells treated with the combination of SP600125 and TRAIL or anti-Apo1, respectively, without caspase inhibitors; $\mathrm{p}<0.001$ ). DMSO, dimethyl sulfoxide; MAPK, mitogen-activated protein kinase; SP, SP600125; TRAIL, tumour necrosis factor-related apoptosis-inducing ligand.
A

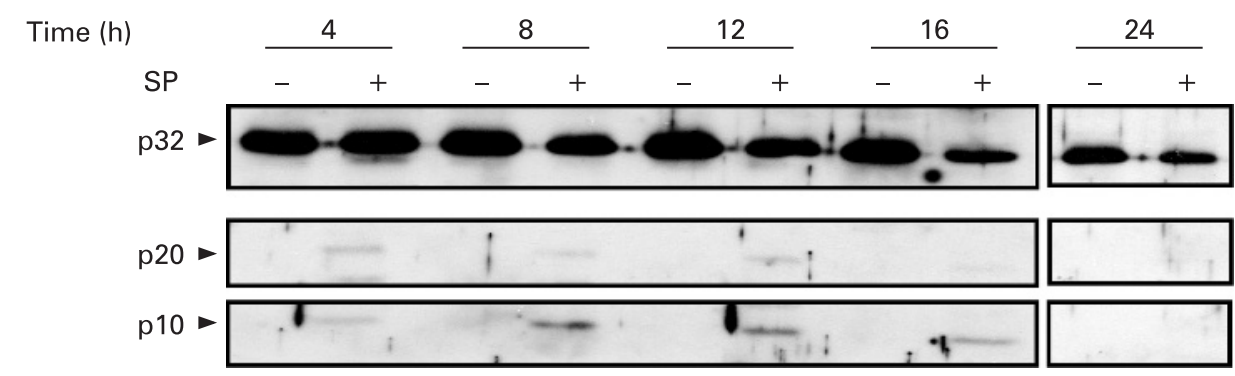

B

Time (h)
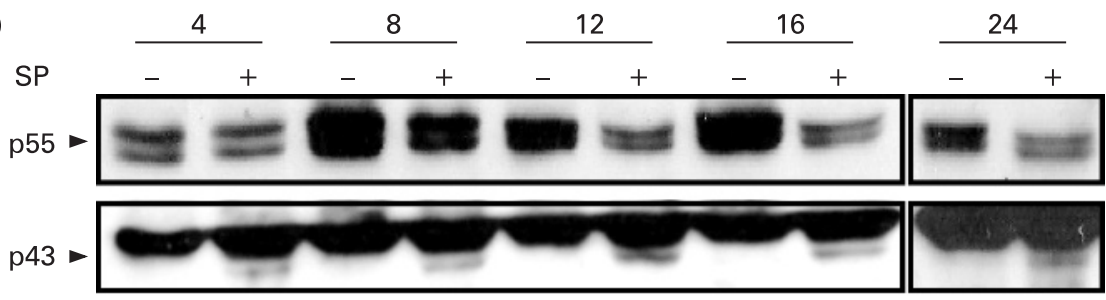

p18
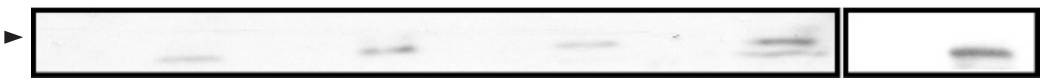

C

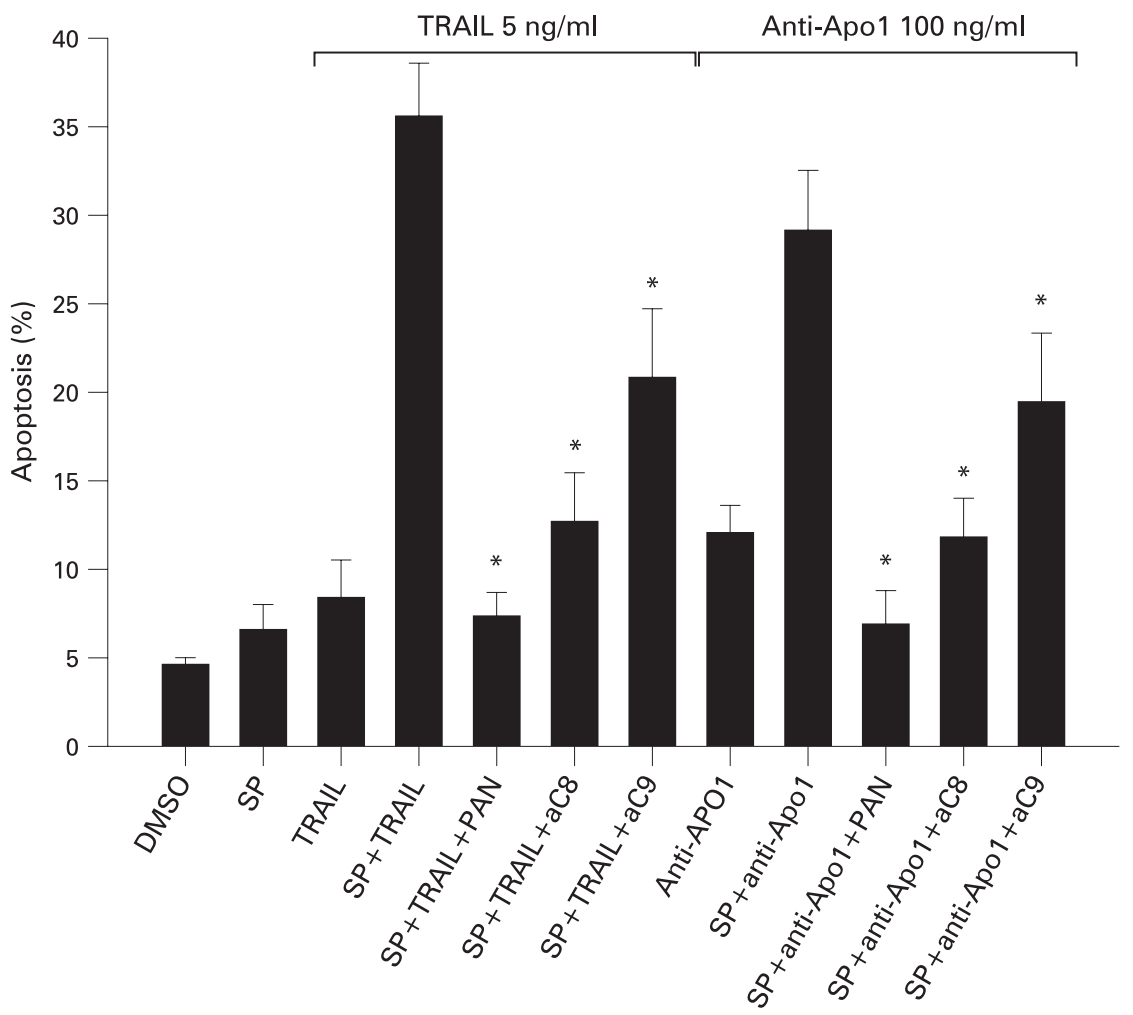

analysis was carried out using TINA software (Raytest, Straubenhardt, Germany).

\section{Fast activated cell-based ELISA (FACE)}

The phospho-JNK FACE kit was purchased from Active Motif (Carlsbad, California, USA). Three thousand cells per well were seeded overnight in 96-well plates. Cells were stimulated as indicated, then fixed in $4 \%$ formalin and plates were stored at $4^{\circ} \mathrm{C}$. Incubation with primary and secondary antibody and standardisation for cell count using in-well crystal violet stain was done according to the manufacturer's instructions.

\section{Statistics}

For statistical evaluation the t test for independent samples has been used. Differences have been regarded as significant for $p$ values at least less than 0.05 and were indicated in each figure. Unless otherwise specified, all values represent the mean and standard deviation of triplicate values from the same 


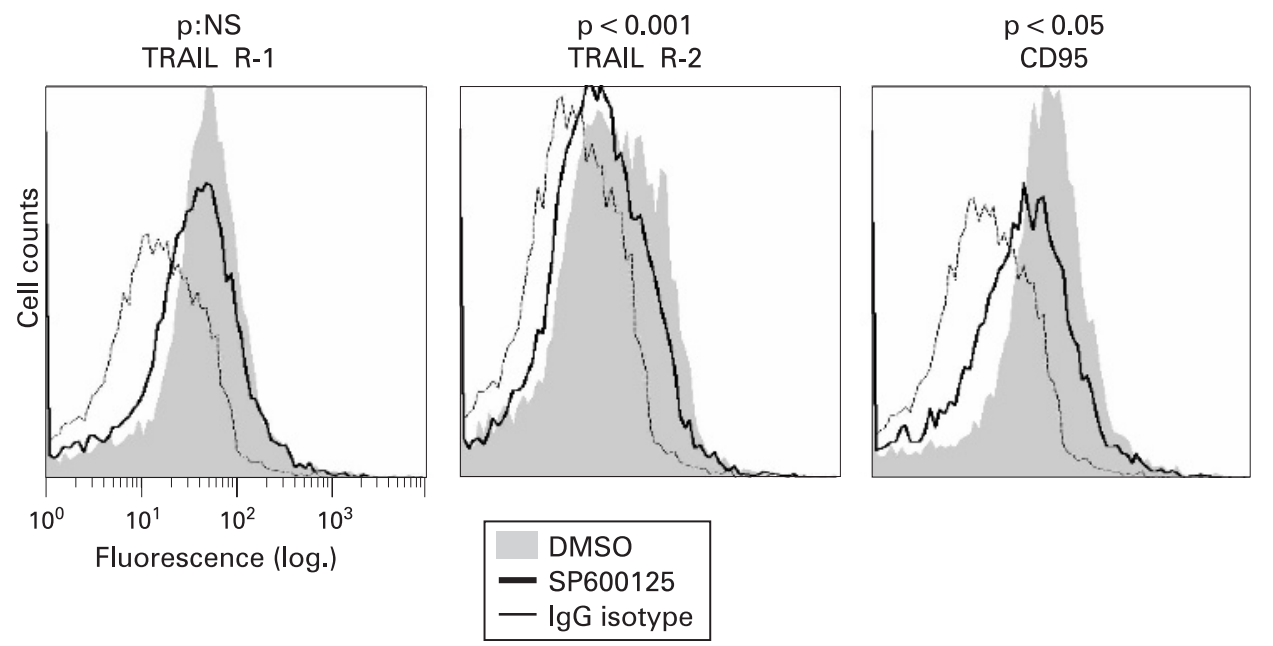

Figure 7 Surface expression of CD95 and TRAIL receptors in Chang cells after treatment with DMS0 or SP600125. Surface staining of CD95, TRAIL$\mathrm{R} 1$ or TRAIL-R2 was performed $24 \mathrm{~h}$ after stimulation. In comparison to an isotype-matched control mlgG1 monoclonal antibody (thin line), receptor expression of cells treated with SP600125 alone are shown as a bold line; cells treated with DMSO as a shaded area. CD95 and TRAIL-R2 but not TRAIL-R1 were significantly downregulated in SP600125-treated cells versus DMSO-treated cells. The data represent one of at least three independent experiments with similar results. Significance levels of each receptor expression versus DMSO-treated cells are reported. DMSO, dimethyl sulfoxide; NS, not significant; TRAIL, tumour necrosis factor-related apoptosis-inducing ligand.

experiment, three or more experiments providing similar results and significance levels. Calculations were performed by the program Sigma Plot (SPSS, version 7.0).

\section{RESULTS \\ JNK inhibition enhances receptor-mediated apoptosis and causes cell cycle arrest}

To evaluate the effects of JNK inhibition on receptor-mediated apoptosis in hepatocellular carcinoma, we used Chang cells as a model system. Cells were treated with TRAIL, the CD95 agonistic antibody anti-Apo1 or with the JNK inhibitor SP600125 as indicated. The efficacy of SP600125 as JNK inhibitor was confirmed by the inhibition of methyl methane sulfonate (MMS)-induced c-Jun phosphorylation (fig 1A). While Chang cells proved resistant to TRAIL, anti-Apo1 or to SP600125 alone (fig 1A,B), addition of SP600125 synergistically increased apoptosis rates triggered by TRAIL or anti-Apo1 (ie, apoptosis increased from $7 \%$ to $55 \%$ after stimulation with TRAIL at the concentration of $25 \mathrm{ng} / \mathrm{ml}$ ). After $16 \mathrm{~h}$ of incubation with SP600125 and TRAIL or anti-Apo1, Chang cells displayed the characteristic morphological features of apoptosis, such as cell shrinkage and membrane blebbing. Hoechst staining of the same cells showed typical nuclear fragmentation (fig 2A-F).

\section{Sensitisation of hepatoma cells to apoptosis by SP600125 is a specific effect of JNK inhibition and is independent of cell line and p53 status}

To rule out the possibility that the increased sensitivity to apoptosis could be due to non-specific effects of SP600125 on kinases other than JNK, we additionally targeted JNK by specific interfering RNA sequences (fig 3A). JNK inhibition by siRNA alone did not induce significant apoptosis, but clearly increased the pro-apoptotic effect of TRAIL-receptor (TRAIL-R) and CD95 stimulation (fig 3B). This confirms that JNK activity does not affect basal apoptosis, but acts to suppress apoptosis mediated by membrane receptors.

Similarly to the effect observed in Chang cells, the combination of SP600125 and anti-Apo1 or TRAIL also induced apoptosis in HepG2 and Huh7 hepatoma cells (fig 3C). As expected, due to the lack of a functional CD95 receptor in this cell line, SP600125 only increased TRAIL-induced apoptosis, but failed to enhance CD95-mediated apoptosis in Huh7..$^{30}$ Thus, we conclude that JNK inhibition sensitises hepatoma cells to apoptosis, and is not cell-line specific. The fact that SP600125 greatly increases TRAIL sensitivity of Huh7 cells, which carry a mutated p53, also shows that the effect of JNK inhibition on apoptosis is not dependent on p53 status.

\section{TRAIL-R- and CD95-mediated JNK activation represents a negative feedback mechanism that interferes with receptor- induced apoptosis in hepatoma cells}

To assess the effect of the pro-apoptotic receptor stimulation on JNK activity we used ELISA to measure the extent of JNK activation in Chang cells, $1 \mathrm{~h}$ after stimulation with increasing doses of TRAIL. As shown in fig 4A, stimulation of Chang cells with TRAIL showed a dose-dependent increase of phosphorylation and thereby activation of JNK, while the total amount of JNK remained unaffected (fig 4A). Subsequently, we also assessed the time dependency of JNK activation and the total amount of JNK by measuring phosphorylated JNK ( $p$-JNK) levels at different time points after stimulation. Incubation of Chang cells with $5 \mathrm{ng}$ TRAIL or 100 ng anti-Apo1 resulted in an early increase of p-JNK levels which peaked after stimulation and progressively diminished over $5 \mathrm{~h}$. Simultaneous administration of SP600125 effectively reduced TRAIL and anti-Apo1-induced JNK phosphorylation (fig 4B), without affecting overall expression of JNK (fig 4C). Thus, TRAIL-R- and CD95-mediated JNK activation is likely to represent a negative feedback mechanism by which hepatoma cells become resistant to receptor-induced apoptosis. To evaluate whether the sensitivity to JNK inhibition is due to JNK over-expression, and/or constitutive activation of JNK in our in vitro system, the amount of p-JNK in Chang, HepG2 and Huh7 hepatoma cell lines was assessed by western blot in comparison to that of primary cultivated hepatocytes. In agreement with data from primary tumours, ${ }^{22}$ the level of p-JNK in the cell lines used in our system was remarkably elevated in comparison to that 
Figure 8 JNK inhibition does not affect TRAIL-mediated apoptosis in primary hepatocytes. Primary hepatocytes were treated with anti-Apo1 (A) TRAIL (B) in combination with SP600125 $(20 \mu \mathrm{mol} / \mathrm{l})$ or DMSO as indicated. $10^{5}$ cells/well were seeded in collagen-coated 12-well plates. Values represent cell viability, as measured by FACS, non-treated cells being set to $100 \%$. Average and standard deviation values are representative of values obtained from three different independent donors ( $\uparrow$ not significant). (C-F) Light and fluorescence microscopy features of primary hepatocytes after Hoechst staining (left and right panels, respectively). Cells were harvested after $24 \mathrm{~h}$ incubation with TRAIL in combination with DMSO $(\mathrm{C}, \mathrm{D})$ or SP600125 (E,F; magnification, $\times 100)$. DMSO, dimethyl sulfoxide;

FACS, fluorescence-activated cell sorting; JNK, cJun N-terminal kinase;

TRAIL, tumour necrosis factor-related apoptosis-inducing ligand.
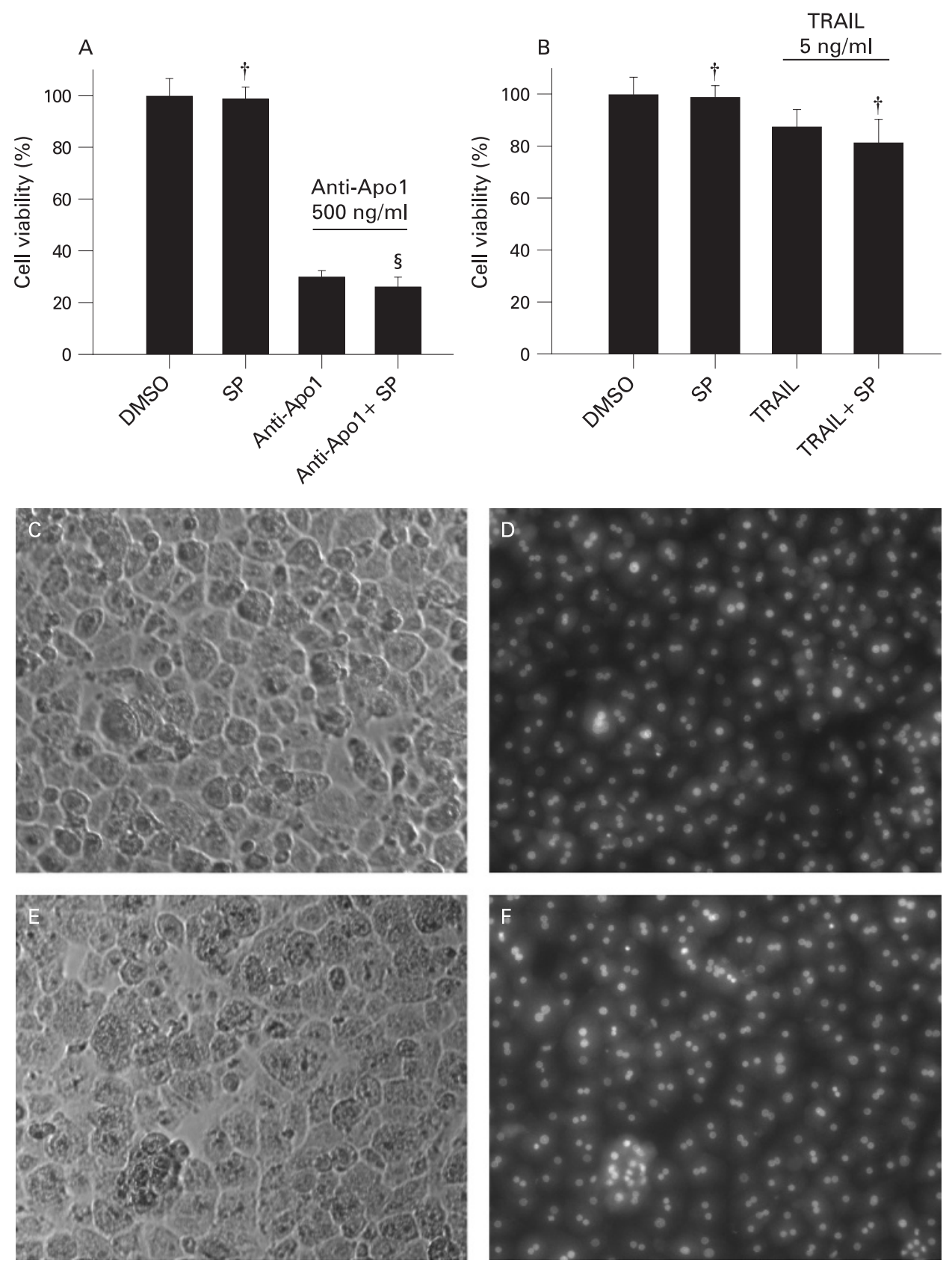

observed in primary hepatocytes from three different donors (fig 4D).

\section{c-Jun inhibition enhances receptor mediated apoptosis}

To investigate whether JNK exerts its anti-apoptotic affect through activation of c-Jun and AP-1 transcriptional activity ${ }^{24}$ we also targeted c-Jun with specific RNA interference. siRNA transfection of HepG2 cells with c-Jun siRNA effectively decreased c-Jun at the protein level (fig 5A). RNA interference also led to a 10-fold decrease of the AP-1 transcription activity, as determined by reporter luciferase activity $24 \mathrm{~h}$ after transfection (fig 5A). siRNA transfection, application of $10 \mathrm{ng} / \mathrm{ml}$ of the CD95 ligand (LZCD95L) or of $2.5 \mathrm{ng} / \mathrm{ml}$ TRAIL for $16 \mathrm{~h}$ did not significantly affect apoptosis rates. However, apoptosis greatly increased up to $64 \%$ and $69 \%$ when the CD95 ligand or TRAIL were administered in cells previously transfected with c-Jun-targeting siRNA (fig 5B). Thus, inhibition of c-Jun resulted in a similar pro-apoptotic effect as inhibition of JNK suggesting that c-Jun/AP-1 transcriptional activity contributes to the pro-apoptotic effect observed after JNK inhibition.

\section{Inhibition of MAPK facilitates receptor-mediated activation of caspase 8, independently of membrane receptor expression}

To determine the level of interaction between JNK inhibition and the receptor-mediated pro-apoptotic pathway, caspase cleavage was assessed. Co-treatment of Chang cells with SP600125 and TRAIL or anti-Apo1 increased activation of both caspase 3 and 8. Early appearance of cleaved fragments of caspase 8 demonstrates that caspase 8 activation is an early event in the induction of apoptosis, and not a feedback phenomenon occurring at later time points (fig 6A,B). To further investigate the interaction between JNK and caspase activation we analysed the effects of several caspase inhibitors 

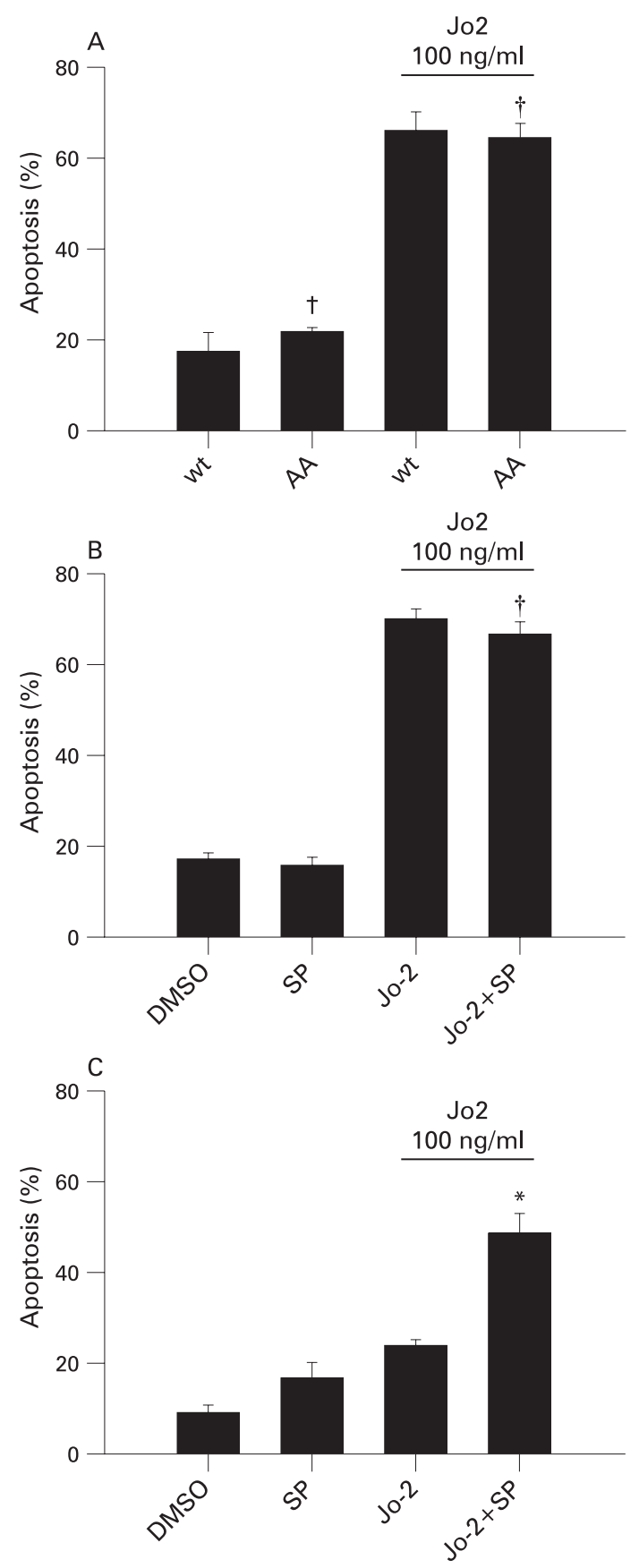

Figure 9 Sensitivity of isolated primary mouse hepatocytes is independent of c-Jun phosphorylation or JNK activity. $(A, B) 2.0 \times 10^{5}$ hepatocytes, isolated from mice expressing the mutated form of c-Jun lacking the activating phosphorylation site (AA) or wild-type (wt) mice were seeded in collagen-coated 12-well plates and allowed to attach for $2 \mathrm{~h}$. Apoptosis rates were determined by measuring sub-G1 events using FACS analysis $16 \mathrm{~h}$ after stimulation. The graph shows mean apoptosis rates and SD of one representative experiment, performed in triplicate, and repeated at least three times. (A) Apoptosis rates in hepatocytes isolated from A/A mice and from wild-type after incubation with $100 \mathrm{ng} / \mathrm{ml}$ of the mouse CD95 agonistic antibody Jo-2 for $16 \mathrm{~h}$ or incubated with medium alone. (B) Apoptosis rates in wild-type hepatocytes after stimulation with Jo-2 alone or in combination with SP600125.

(C) Apoptosis rates of HepA1-6 mouse hepatoma cells, $16 \mathrm{~h}$ after treatment with SP600125, Jo-2 or a combination of both $\left({ }^{*} p<0.01\right.$; $\dagger N S)$. DMSO, dimethyl sulfoxide; JNK, cJun -N-terminal kinase; SP, SP600125. on the synergistic effect of SP600125 and TRAIL or anti-Apo1. The pancaspase inhibitor Z-VAD-FMK abolished any apoptotic effect of TRAIL and anti-Apo1, even when combined with SP600125. A similar effect could be observed after administration of the caspase 8 inhibitor Z-IETD-FMK. Incubation with the caspase 9 inhibitor Z-LEHD-FMK also significantly reduced apoptosis rates triggered by combined treatment of Chang cells with SP600125 and TRAIL or anti-APO1 (fig 6C). This clearly demonstrates that increased recruitment of caspase 8 after TRAIL-receptor or CD95 stimulation is an essential mechanism by which JNK inhibition sensitises hepatoma cells to apoptosis. The fact that caspase 9 activation also contributes to TRAIL and anti-Apo1-induced apoptosis after JNK inhibition is in agreement with the notion that hepatocytes are type 2 cells, ie, are capable of reinforcing apoptotic signalling initiated by the membrane receptors through the recruitment of the mitochondrial pathway.

Since loss of membrane receptors plays a role in carcinogenesis, ${ }^{31} 32$ and several chemotherapeutic drugs have been shown to increase expression of death receptors, ${ }^{33}$ we assessed whether the increased caspase 8 recruitment observed after JNK/Jun inhibition could be due to an increase of surface receptor expression. As judged by FACS analysis, treatment with SP600125 did not lead to an increase of membrane receptors. Instead, a significant decrease of CD95 and TRAIL-R2 (fold decreases of 0.69 (SD 0.1) and 0.58 (SD 0.1), respectively; $\mathrm{p}<0.05$ ), but not of TRAIL-R1 could be detected (fig 7). This indicates that JNK inhibition sensitises hepatoma cells to apoptosis by affecting the intracellular apoptotic signalling pathways.

\section{Inhibition of JNK does not sensitise primary human hepatocytes to receptor-mediated apoptosis}

To assess whether the effect of JNK inhibition is specific for cancer thus representing a feasible therapeutic option for HCC, we also evaluated the effect of JNK inhibition on sensitivity to TRAIL of normal cells. To this end, primary normal human hepatocytes, cultivated for 1 day after liver perfusion, were incubated with anti-Apo1 or TRAIL in the presence or absence of SP600125. As reported previously, ${ }^{9}$ hepatocytes proved highly sensitive to CD95 stimulation (fig 8A). In contrast, a concentration of $5 \mathrm{ng} / \mathrm{ml}$ of TRAIL only marginally reduced cell viability. In both cases, concomitant JNK inhibition by SP600125 did not increase apoptosis (fig 8B) as judged by FACS analysis, morphological features of cells and Hoechst nuclear staining (fig 8C-F). JNK activity therefore strongly influenced the sensitivity to apoptosis inducing surface receptors cancer cells, but not in normal cells.

Sensitivity of primary mouse hepatocytes to receptor-mediated apoptosis is independent of c-Jun phosphorylation and JNK activity

Since no specific pharmacological inhibitor of c-Jun is available to assess the effect of the mitogen-activated protein kinase (MAPK) inhibition downstream of JNK, we compared the sensitivity to CD95 stimulation in hepatocytes isolated from wild-type mice with that of hepatocytes obtained from mice carrying a mutation at the site of c-Jun phosphorylation (JunA/ A). ${ }^{28}$ Confirming that c-Jun phosphorlyation does not affect CD95-mediated cell death in normal cells, basal apoptosis rates in hepatocytes isolated from JunA/A mice did not differ from that observed in cells isolated from wild-type mice. Moreover, administration of the murine CD95 agonistic antibody Jo-2 
triggered apoptosis in hepatocytes from JunA/A mice at the same rate as in wild-type hepatocytes (fig 9A). JNK inhibition by SP600125 also did not affect apoptosis rates (fig 9B). Failure to sensitise mouse cells was not due to a species specific effect of SP600125 in human cells, because SP600125 greatly sensitised HepA1-6 mouse hepatoma cell line to the action of Jo-2 (fig 9C).

\section{DISCUSSION}

JNK is constitutively active in many tumours and in as many as $75 \%$ of hepatocellular carcinomas. The mechanism by which this kinase contributes to the carcinogenesis of tumours, however, still remains largely an object of debate ${ }^{19} 3435 \mathrm{We}$ show here how inhibition of JNK affects proliferation and apoptotic properties of hepatocellular carcinoma cells, making the targeting of this signalling pathway a potential target for the treatment of these tumours.

TRAIL exerts a primary role in the surveillance of tumour formation as demonstrated by several animal models as well as clinical data. We also recently reported that the over-expression of OPG, a decoy receptor for TRAIL regulated by $\beta$-catenin, in patients affected by colorectal carcinoma correlates with tumour stage and metastasis formation. ${ }^{5}$

In our system JNK inhibition caused cell cycle arrest and sensitised cancer cells to TRAIL-mediated apoptosis. TRAIL administration resulted in the increase of JNK activity and this effect could be reverted by administration of SP600125. This suggests that early JNK activation upon TRAIL administration represents a negative feedback mechanism of apoptosis inhibition in cancer cells. It is therefore likely that the frequently observed over-expression of JNK in cancer cells ${ }^{24}$ results from the selection of clones resistant to endogenous TRAIL following a gain of function of JNK as negative regulator of apoptosis. The association of SP600125 and TRAIL synergised to induce apoptosis selectively in cancer cells. Thereby anti-tumour concentrations of TRAIL could be tapered to low doses. Thus, JNK inhibition might also improve both efficacy and safety of TRAIL administration for therapeutic purposes.

Treatment of Chang cells with SP600125 led to increased recruitment and activation of caspase 8 upon the stimulation of the death receptors. However, increased caspase 8 recruitment was not due to an increase of the quota of TRAIL receptor or CD95 on the cell membranes. Expression of TRAIL-R1, TRAILR2 and CD95 on the cell surface was not increased as a consequence of JNK inhibition; instead, a decrease of TRAIL-R2 and of CD95 could be detected (fig 7).

Our findings describing an anti-apoptotic role for JNK are in contrast to previous data showing that JNK can also act as mediator of apoptosis: prolonged JNK activation has been shown to be the essential mediator of cell death in response to TNF and oxidative stress in non-transformed cells. ${ }^{19} 20$ Furthermore, several publications showed recently that JNK might act pro-apoptotically, mediating cell death triggered by TRAIL in diseased, non-transformed hepatocytes as a consequence of several pathological situations such as adenoviral hepatitis, ${ }^{36}$ hepatitis $\mathrm{C}$ virus hepatitis, ${ }^{37}$ cholestatic liver disease ${ }^{38}$ and non-alcoholic steatohepatitis. ${ }^{39}$

Our finding that JNK inhibition acts to enhance apoptosis in liver tumours suggests that JNK in the liver might have different roles in non transformed cells under stress conditions ${ }^{14} 1920$ and in cancer cells.

A different effect of JNK inhibition in cancer cells and in nontumour cells is likely to have relevant clinical significance: liver cancer arises in most cases in the context of a diseased liver where JNK, as shown by the aforementioned papers, acts pro-apoptotically to mediate TRAIL toxicity. Use of JNK inhibitors to sensitise cancer cells to TRAIL might open the way for the use of TRAIL in the therapy of liver tumours, since their use may reduce liver damage and TRAIL toxicity in nontumour tissues while sensitising malignant cells to TRAIL. Remarkably, in many of the recent works investigating the mechanism of TRAIL toxicity in non-tumour cells showed that the pro-apoptotic effect of TRAIL was mediated in these cells by increased TRAIL-R2 in adenoviral hepatitis, ${ }^{36}$ bile-acid-induced TRAIL sensitisation ${ }^{38}$ and in liver steatosis ${ }^{39}$ this is in agreement with the fact that in our system JNK inhibition reduced the expression of TRAIL-R2 and of CD95 but not that of TRAIL-R1 (fig 7); however, reduction of TRAIL-R2 did not impair the proapoptotic effect of TRAIL in cancer cells, suggesting that JNK might act to reduce TRAIL toxicity in normal cells by decreasing the amount of TRAIL receptors on the cell membranes while sensitising cancer cells by enhancing the intracellular signalling of TRAIL.

Inhibition of JNK signalling effectively sensitised tumour cells to TRAIL independently of the tumour suppressor p53 (fig 3). Mutations of p53 occur in approximately $50 \%$ of all human tumours ${ }^{40}$ and represent a major cause of tumour resistance to therapy. ${ }^{41}$ Therefore inhibition of the MAPK signalling pathway combined with administration of TRAIL could overcome frequent mechanisms of resistance to traditional chemotherapy.

In summary, these data shed new light on how the frequent hyperactivation of JNK in HCC is likely to contribute to carcinogenesis by causing resistance to endogenous TRAIL. Also, JNK inhibition promises to address the problems bound to the exogenous administration of TRAIL for therapeutic purposes by sensitising cancer cells to receptor-mediated apoptosis and by reducing its potential toxicity by decreasing the concentrations needed to trigger apoptosis in cancer cells. JNK inhibition might furthermore increase intrinsic resistance of non-transformed cells to TRAIL.

Acknowledgements: We are grateful to Dr P H Krammer (DKFZ, Heidelberg, Germany) for anti-Apo1 and caspase 8 antibodies, to Dr H Walczak (Imperial College, London, UK) for valuable discussions, to N Sonuc (Ludwig Maximillian University, Munich, Germany) for c-Jun siRNA experiments, and to the Foundation for Human Tissue and Cell Research (HTCR, Regensburg, Germany) which made human liver tissue available.

Funding: This study was funded by the Deutsche Forschungsgemeinschaft (DFG) grant to the KF0128 to BG, and the Förderprogramm für Forschung und Lehre (FöFoLe) of the Ludwig Maximilian University to EDT.

Competing interests: None.

Ethics approval: Tissue sample collection from human liver resections was performed according to the guidelines of the charitable state-controlled foundation Human Tissue and Cell Research.

\section{REFERENCES}

1. El Serag HB, Rudolph KL. Hepatocellular carcinoma: epidemiology and molecular carcinogenesis. Gastroenterology 2007;132:2557-76.

2. Eichhorst ST, Krammer PH. Derangement of apoptosis in cancer. Lancet 2001;358:345-6.

3. Cretney $\mathbf{E}$, Takeda K, Yagita $H$, et al. Increased susceptibility to tumor initiation and metastasis in TNF-related apoptosis-inducing ligand-deficient mice. J Immunol 2002;168:1356-61.

4. Eichhorst ST. Modulation of apoptosis as a target for liver disease. Expert Opin Ther Targets 2005;9:83-99.

5. De Toni EN, Thieme SE, Herbst A, et al. OPG is regulated by beta-catenin and mediates resistance to TRAlL-induced apoptosis in colon cancer. Clin Cancer Res 2008;14:4713-8.

6. Ashkenazi A, Herbst RS. To kill a tumor cell: the potential of proapoptotic receptor agonists. J Clin Invest 2008;118:1979-90.

7. Ashkenazi A, Pai RC, Fong S, et al. Safety and antitumor activity of recombinant soluble Apo2 ligand. J Clin Invest 1999;104:155-62. 
8. Ganten TM, Koschny R, Sykora J, et al. Preclinical differentiation between apparently safe and potentially hepatotoxic applications of TRAIL either alone or in combination with chemotherapeutic drugs. Clin Cancer Res 2006;12:2640-6.

9. Jo M, Kim TH, Seol DW, et al. Apoptosis induced in normal human hepatocytes by tumor necrosis factor-related apoptosis-inducing ligand. Nat Med 2000;6:564-7.

10. Garber K. New apoptosis drugs face critical test. Nat Biotechnol 2005;23:409-11.

11. Tolcher AW, Mita M, Meropol NJ, et al. Phase I pharmacokinetic and biologic correlative study of mapatumumab, a fully human monoclonal antibody with agonist activity to tumor necrosis factor-related apoptosis-inducing ligand receptor-1. J Clin Oncol 2007;25:1390-5.

12. Gajewski TF. On the TRAIL toward death receptor-based cancer therapeutics. J Clin Oncol 2007;25:1305-7.

13. Armeanu S, Lauer UM, Smirnow I, et al. Adenoviral gene transfer of tumor necrosis factor-related apoptosis-inducing ligand overcomes an impaired response of hepatoma cells but causes severe apoptosis in primary human hepatocytes. Cancer Res 2003;63:2369-72.

14. Volkmann X, Fischer U, Bahr MJ, et al. Increased hepatotoxicity of tumor necrosis factor-related apoptosis-inducing ligand in diseased human liver. Hepatology 2007;46:1498-508

15. Walczak H, Miller RE, Ariail K, et al. Tumoricidal activity of tumor necrosis factorrelated apoptosis-inducing ligand in vivo. Nat Med 1999;5:157-63.

16. Pathil A, Armeanu S, Venturelli S, et al. HDAC inhibitor treatment of hepatoma cells induces both TRAIL-independent apoptosis and restoration of sensitivity to TRAIL. Hepatology 2006;43:425-34.

17. Koschny R, Ganten TM, Sykora J, et al. TRAIL/bortezomib cotreatment is potentially hepatotoxic but induces cancer-specific apoptosis within a therapeutic window. Hepatology 2007:45:649-58.

18. De Toni EN, Kuntzen C, Gerbes AL, et al. P60-C-src suppresses apoptosis through inhibition of caspase 8 activation in hepatoma cells, but not in primary hepatocytes. $J$ Hepatol 2007;:46:682-91.

19. Czaja MJ. The future of GI and liver research: editorial perspectives. III. JNK/AP-1 regulation of hepatocyte death. Am J Physiol Gastrointest Liver Physiol 2003;284:G875-9.

20. Wang $\mathbf{Y}$, Singh R, Lefkowitch $\mathrm{JH}$, et al. Tumor necrosis factor-induced toxic liver injury results from JNK2-dependent activation of caspase-8 and the mitochondrial death pathway. J Biol Chem 2006;281:15258-67.

21. Sakurai T, Maeda S, Chang L, et al. Loss of hepatic NF-kappa B activity enhances chemical hepatocarcinogenesis through sustained c-Jun N-terminal kinase 1 activation. Proc Natl Acad Sci U S A 2006;103:10544-51.

22. Schmidt CM, McKillop IH, Cahill PA, et al. Increased MAPK expression and activity in primary human hepatocellular carcinoma. Biochem Biophys Res Commun 1997;236:54-8.

23. Yuen MF, Wu PC, Lai VC, et al. Expression of c-Myc, c-Fos, and c-jun in hepatocellular carcinoma. Cancer 2001;91:106-12.
24. Guo L, Guo Y, Xiao S, et al. Protein kinase p-JNK is correlated with the activation of AP-1 and its associated Jun family proteins in hepatocellular carcinoma. Life Sci 2005;77:1869-78.

25. Kuntzen C, Sonuc N, De Toni EN, et al. Inhibition of C-Jun-N-terminal-kinase sensitizes tumor cells to CD95-induced apoptosis and induces G2/M cell cycle arrest. Cancer Res 2005;65:6780-8.

26. Thasler WE, Weiss TS, Schillhorn K, et al. Charitable State-Controlled Foundation Human Tissue and Cell Research: ethic and legal aspects in the supply of surgically removed human tissue for research in the academic and commercial sector in Germany. Cell Tissue Bank 2003;4:49-56.

27. Weiss TS, Pahernik S, Scheruebl I, et al. Cellular damage to human hepatocytes through repeated application of 5-aminolevulinic acid. J Hepatol 2003;38:476-82.

28. Behrens A, Sibilia M, Wagner EF. Amino-terminal phosphorylation of c-Jun regulates stress-induced apoptosis and cellular proliferation. Nat Genet 1999;21:326-9.

29. Nicoletti I, Migliorati G, Pagliacci MC et al. A rapid and simple method for measuring thymocyte apoptosis by propidium iodide staining and flow cytometry. J Immunol Methods 1991;139:271-9.

30. Muller M, Strand S, Hug H, et al. Drug-induced apoptosis in hepatoma cells is mediated by the CD95 (APO-1/Fas) receptor/ligand system and involves activation of wild-type p53. J Clin Invest 1997;99:403-13.

31. Ito $\mathbf{Y}$, Monden $\mathrm{M}$, Takeda $\mathrm{T}$, et al. The status of Fas and Fas ligand expression can predict recurrence of hepatocellular carcinoma. Br J Cancer 2000;82:1211-7.

32. Shin MS, Kim HS, Lee SH, et al. Mutations of tumor necrosis factor-related apoptosis-inducing ligand receptor 1 (TRAIL-R1) and receptor 2 (TRAIL-R2) genes in metastatic breast cancers. Cancer Res 2001;61:4942-6.

33. Ganten TM, Haas TL, Sykora J, et al. Enhanced caspase-8 recruitment to and activation at the DISC is critical for sensitisation of human hepatocellular carcinoma cells to TRAIL-induced apoptosis by chemotherapeutic drugs. Cell Death Differ 2004;11(Suppl 1):S86-S96.

34. Kennedy NJ, Davis RJ. Role of JNK in tumor development. Cell Cycle 2003;2:199-201

35. Manning AM, Davis RJ. Targeting JNK for therapeutic benefit: from junk to gold? Nat Rev Drug Discov 2003;2:554-65.

36. Mundt B, Wirth T, Zender L, et al. Tumour necrosis factor related apoptosis inducing ligand (TRAIL) induces hepatic steatosis in viral hepatitis and after alcohol intake. Gut 2005; 54:1590-6.

37. Mundt B, Kuhnel F, Zender L, et al. Involvement of TRAIL and its receptors in viral hepatitis. FASEB J 2003;17:94-6.

38. Higuchi H, Grambihler A, Canbay A, et al. Bile acids up-regulate death receptor 5/ TRAIL-receptor 2 expression via a c-Jun $\mathrm{N}$-terminal kinase-dependent pathway involving Sp1. J Biol Chem 2004;279:51-60.

39. Malhi H, Barreyro FJ, Isomoto $\mathrm{H}$, et al. Free fatty acids sensitise hepatocytes to TRAIL mediated cytotoxicity. Gut 2007:56:1124-31.

40. Owen-Schaub LB, Zhang W, Cusack JC, et al. Wild-type human p53 and a temperature-sensitive mutant induce Fas/APO-1 expression. Mol Cell Biol 1995; 15:3032-40.

41. Levine AJ. p53, the cellular gatekeeper for growth and division. Cell 1997;88:323-31.

\section{Drug and Therapeutics Bulletin (DTB)}

Your key source of unbiased, independent advice

For over 45 years DTB has been an independent, indispensable part of evidence-based clinical practice. DTB offers healthcare professionals detailed assessment of, and practical advice on, individual medicines and other treatments, groups of treatment and the overall management of disease.

DTB is now also available online at http://dtb.bmj.com:

- browse or search all DTB content from the latest issue back to 1994

- email alerting, sophisticated searching, RSS feeds and full text links from cited references

- interactive services such as My Folders for quick access to articles that you have viewed previously and My Searches to save and re-use useful searches

- comment online on any DTB article

To subscribe, or for further information, please visit http://dtb.bmj.com 


\section{GUT}

\section{JNK inhibition sensitises hepatocellular carcinoma cells but not normal hepatocytes to the TNF-related apoptosis-inducing ligand}

S R Mucha, A Rizzani, A L Gerbes, et al.

Gut 2009 58: 688-698 originally published online December 23, 2008 doi: $10.1136 /$ gut.2008.154625

Updated information and services can be found at:

http://gut.bmj.com/content/58/5/688.full.html

\section{These include:}

References This article cites 41 articles, 16 of which can be accessed free at: http://gut.bmj.com/content/58/5/688.full.html\#ref-list-1

Article cited in:

http://gut.bmj.com/content/58/5/688.full.html\#related-urls

Email alerting Receive free email alerts when new articles cite this article. Sign up in service the box at the top right corner of the online article.

Topic Articles on similar topics can be found in the following collections Collections

Notes

To request permissions go to:

http://group.bmj.com/group/rights-licensing/permissions

To order reprints go to:

http://journals.bmj.com/cgi/reprintform

To subscribe to BMJ go to:

http://group.bmj.com/subscribe/ 